\title{
A Green Electrorefining Process for Production of Pure Lead from Methanesulfonic Acid Medium
}

\author{
Bingjie Jin ${ }^{\text {a, }}$, David B. Dreisinger ${ }^{\mathrm{b}, \uparrow}$ \\ ${ }^{a}$ State Key Laboratory of Complex Nonferrous Metal Resources Clean Utilization, Kunming \\ University of Science and Technology, 650093 Kunming, Yunnan, China \\ ${ }^{\mathrm{b}}$ Department of Materials Engineering, University of British Columbia, V6T 1Z4 Vancouver, \\ Canada
}

\begin{abstract}
A green electrorefining process for production of pure lead from methanesulfonic acid (MSA) medium was studied. The conductivities of lead - MSA solutions have been measured and modeled to characterize the electrorefining medium. The effects of current density, electrode spacing, electrorefining temperature, lead concentration, free-MSA concentration and electrorefining time on the electrorefining process were investigated. The cell voltage and specific energy consumption of the electrorefining process increase with an increase of current density, electrode spacing and electrorefining time, and decrease with an increase of electrorefining temperature, lead concentration and free-MSA concentration. The operating parameters of the electrorefining process for production of pure lead from MSA medium in this study have a widely acceptable range as follows: current density $150-250 \mathrm{~A} / \mathrm{m}^{2}$, electrode spacing $3.0-6.0 \mathrm{~cm}$, electrorefining temperature $293.5-313.5 \mathrm{~K}$, lead concentration $60-150 \mathrm{~g} / \mathrm{L}$ and a free-MSA concentration $100 \mathrm{~g} / \mathrm{L}$. The cathodic current efficiency was in excess of $99 \%$ and the specific energy consumption was below $110 \mathrm{~kW} \cdot \mathrm{h} / \mathrm{t}-\mathrm{Pb}$. The lead content of the cathodic lead was in excess of $99.99 \%$.
\end{abstract}

\section{Keywords}

Lead; Electrorefining; Methanesulfonic acid; Conductivity; Mathematical model

\section{Introduction}

Pyro-refining and electrorefining are two mainly processes for lead refining. At present, 35\% and $65 \%$ of lead are produced by pyro-refining and electrorefining, respectively. There are some drawbacks of pyro-refining, such as: emissions of lead and $\mathrm{SO}_{2}$ fumes which are very hard to

\footnotetext{
* Corresponding author. Bingjie JIN, Tel.: +86 871 65162008, E-mail address: jinbingjie18@ 163.com Corresponding author. David B. Dreisinger, Tel.: +1 604-822-4805, E-mail address: david.dreisinger@ubc.ca
} 
control. The cost of containing emissions is very high to meet the acceptable emission levels. Electrorefining can avoid the emissions of lead and $\mathrm{SO}_{2}$ fumes. Electrorefining allows for a high recovery of precious metals from the anode slime and a low energy consumption.

A variety of solution chemistries are used for lead electrorefining. The hexafluorosilicate solutions were developed for the electrorefining process known as the Betts process [1]. However hexafluorosilicate forms volatile species and decomposes to toxic $\mathrm{HF}$ and $\mathrm{SiF}_{4}$, which cause poor working conditions and general air pollution. The amidosulfonic acid-based solutions were also used for lead electrorefining [2], but one problem is the tendency for the sulfamate anion to be hydrolyzed into ammonia and sulfate. Ammonia can be evaporated from the refining solution and causes environmental pollution. At the same time, the hydrolysis reaction causes the precipitation of lead sulfate and thus a high formation of sludge and a loss of lead from the refining solution.

A range of other solution compositions is used for both lead electroplating and lead electrowinning/refining [3]. These include fluoroborate solutions, perchloric acid solutions and alkaline solutions. The fluoroborate solutions [4,5] undergo hydrolysis in acidic medium to produce hydrofluoric and boric acids with formation of insoluble lead fluoride. There are some disadvantages when using perchloric acid solutions [6], such as: production of chlorine at the anode, production of solid products at the surface of solutions and fouling of the membrane if using membrane electrolysis. Although alkaline solutions [7-10] have the potential of low environmental pollution, the solubility of lead in sodium hydroxide is limited and therefore the process is not attractive.

MSA solutions have some properties including low toxicity, high saturation metal salt solubilities, high conductivity, wider operating window and ease of effluent treatment [11]. Protsenko et al. [12] demonstrated the formation of lead coatings, which were electroplated from an electroplating bath containing MSA. In comparison to lead electroplating from MSA medium, the literature on electrorefining process for production of pure lead from MSA medium is poor. Furthermore, the production of lead by electrorefining from fluosilicic acid medium is more than 6 million tonnes annually. This investigation therefore focuses on the electrorefining process for production of pure lead from MSA medium, in order to address the air pollution problem caused by lead electrorefining from fluosilicic acid medium. At the same time, MSA may also improve the quality of lead produced in the electrorefining process and reduce the energy required.

In this work, the conductivities of lead - MSA solutions were measured to characterize the electrorefining medium and the electrorefining process for production of pure lead from MSA medium was investigated. The variables of interest in the electrorefining process were current density, electrode spacing, electrorefining temperature, lead concentration, free-MSA concentration and electrorefining time.

\section{Evaluation factors}

The purpose of the electrorefining process is to produce a high purity cathode product with good surface appearance and to use minimum energy. Accordingly, the main evaluation factors on the electrorefining process for production of pure lead from MSA medium are cathodic current efficiency $(C C E)$, specific energy consumption (SEC), cathodic lead purity, surface appearance and surface morphology of cathodic lead.

The $C C E$ and $S E C$ are given as (1) and (2), respectively. 


$$
\begin{gathered}
C C E=\frac{m}{I t \mathrm{Q}_{\mathrm{Pb} / \mathrm{Pb}^{2+}}} \times 100 \% \\
S E C=\frac{U I t}{m}
\end{gathered}
$$

where:

$m$, the quantity of cathodic lead during the run time $t$, in grams

$I$, current, in amps

$t$, time, in hours

$\mathrm{Q}_{{\mathrm{Pb} / P \mathrm{~b}^{2+}}^{2+}}$, the electrochemical equivalent of the $\mathrm{Pb} \rightarrow \mathrm{Pb}^{2+}+2 \mathrm{e}$ reaction equal to 3.866 $\mathrm{g} / \mathrm{Ah}$

$U$, cell voltage, in volts.

The purity of cathodic lead was tested by optical emission spectrometric analysis method, AAS and titrimetric method. The surface appearance and surface morphology of cathodic lead were analyzed by optical camera and SEM.

\section{Experimental}

\subsection{Principle}

In this work, the electrochemical process for production of pure lead from MSA medium is shown as (3).

$$
\text { 316L stainless steel (-) }\left|\mathrm{Pb}^{2+}, \mathrm{H}^{+}, \mathrm{CH}_{3} \mathrm{SO}_{3}^{-}\right| \operatorname{raw} \text { lead (+) }
$$

The main cathodic reaction and anodic reaction under direct current are expressed by (4) and (5).

$$
\begin{aligned}
& \mathrm{Pb}^{2+}+2 \mathrm{e}=\mathrm{Pb} \\
& \mathrm{Pb}-2 \mathrm{e}=\mathrm{Pb}^{2+}
\end{aligned}
$$

The Nernst equation is expressed by (6).

$$
E_{\mathrm{Pb}^{2+} / \mathrm{Pb}}=E_{298}^{\theta}+\frac{2.303 R T}{2 F} \lg \alpha_{\mathrm{Pb}^{2+}}
$$

where:

$E_{298}^{\theta}$, reaction standard electrode potential, in volts

$R$, molar gas constant, $R=8.314 \mathrm{~J} /(\mathrm{mol} \cdot \mathrm{K})$

$T$, temperature, in $\mathrm{K}$

$F$, Faraday constant, $F=96500 \mathrm{C} / \mathrm{mol}$ 


$$
\alpha_{\mathrm{Pb}^{2+}}, \mathrm{Pb}^{2+} \text { activity }
$$

Normally, hydrogen will not be produced at the cathode due to the low exchange current density for hydrogen formation on lead and the metals with standard reduction potentials that are greater than the lead standard potential will not dissolve in the electrorefining process.

\subsection{Materials}

The raw lead plates, which were used as anodes, were obtained from Teck Metals Ltd. The chemical composition of the raw lead is shown in table 1. The MSA (Lutropur ${ }^{\circledR}$ MSA 100) was provided by BASF, Germany. The 316L stainless steel plates, which were used as cathodes, were bought from McMaster-Carr. Lead (II) oxide was supplied by Sigma-Aldrich. The additives for the electrorefining process were available in the UBC hydrometallurgical laboratory. The lead MSA solutions were prepared by dissolving lead (II) oxide in MSA solutions prepared with MSA and deionized water.

\subsection{Equipment}

Electrorefining equipment included a custom 0.9-liter rectangular cell, LPS301 DC power supplier of GW Instek, a voltage recorder of OMEGA, an electric-heated thermostatic water bath of Polystat, and a multimeter. Conductivity test equipment was a 4310 bench conductivity meter manufactured by Bibby-Jenway.

\subsection{Procedures}

\subsubsection{Conductivity test}

According to the reaction (7), a theoretical amount of lead (II) oxide powder was weighed accurately and mixed with $30 \mathrm{ml}$ deionized water in a $100 \mathrm{ml}$ beaker flask. Then theoretical amount of MSA was added into the beaker flask by burette. When the lead oxide powder was dissolved completely, the lead - MSA solution in the $100 \mathrm{ml}$ beaker flask was transferred into 100 $\mathrm{ml}$ measuring flask and the volume made up to be $100 \mathrm{ml}$. A sample of $10 \mathrm{ml}$ of the solution was placed in a test tube, which in turn was placed on a test tube holder for performing the conductivity test. The test solution was fresh in each batch test.

$$
2 \mathrm{CH}_{3} \mathrm{SO}_{3} \mathrm{H}+\mathrm{PbO}=\mathrm{Pb}\left[\mathrm{CH}_{3} \mathrm{SO}_{3}\right]_{2}+\mathrm{H}_{2} \mathrm{O}
$$

\subsubsection{Electrorefining process}

A volume of $800 \mathrm{ml}$ lead- MSA solution was prepared and well mixed with additives before each experiment. The lead - MSA solution was placed in the cell. The stainless steel cathode (depositing area $23 \mathrm{~cm}^{2}$ ) and raw lead anode were put into the cell and connected with DC power supply and voltage recorder. In experiments at higher temperature, the cell containing lead - MSA solution was placed in an electric-heated thermostatic water bath to equilibrate and when the desired temperature in the solution was reached, the electrorefining process was started. The 
process time was recorded with a timer. An automatic voltage recorder recorded the cell voltage. When each electrorefining experiment was done, the cathode was taken out of the cell and washed with deionized water and dried at room temperature. The cathode with deposited lead was weighed and recorded. The anode slime was separated from the anode and electrolyte, and then washed using deionized water and dried in an air oven for $24 \mathrm{~h}$. A sample of cathodic lead was sent for analysis $\mathrm{Au}, \mathrm{Ag}, \mathrm{As}, \mathrm{Sb}, \mathrm{Bi}, \mathrm{Sn}, \mathrm{Cu}, \mathrm{Fe}, \mathrm{Zn}$ by optical emission spectrometric analysis method and AAS. A sample of cathodic lead was also sent for analysis of surface morphology by $\mathrm{SEM}$. The contents of $\mathrm{Pb}$ (II) and free MSA were analyzed by titrimetric method using Na2EDTA (for $\mathrm{Pb}$ ) and sodium hydroxide (for MSA) standard solution respectively.

\section{Results and discussion}

\subsection{Conductivity of lead - MSA solutions}

The conductivities of lead - MSA solutions were tested at temperatures from 293.5 to $323 \mathrm{~K}$, lead concentration from 0 to $200 \mathrm{~g} / \mathrm{L}$ and free-MSA concentration from 0 to $200 \mathrm{~g} / \mathrm{L}$. The test range of conductivity was enough to guide the electrorefining process for production of pure lead from MSA medium in this work. The results are shown in Tables 2 - 5.

The results indicate as follows:

(1) The conductivities of lead - MSA solutions increase with an increase of lead concentration without MSA, but the conductivities decrease with an increase of lead concentration for free-MSA concentrations of 50-200 g/L. It may be the formation of $\left[\mathrm{Pb}\left(\mathrm{CH}_{3} \mathrm{SO}_{3}\right)_{3}\right]^{-}[13]$ which causes the decrease of free - $\left(\mathrm{CH}_{3} \mathrm{SO}_{3}\right)^{-}$and hence lower the solution conductivity.

(2) The conductivities of lead - MSA solutions increase with an increase of free - MSA concentration.

(3) The conductivities of lead - MSA solutions increase with an increase of temperature.

A mathematical model for all the conductivities developed using of SPSS statistical software is given as Eq. (8).

$$
\sigma=-44.031+0.172 T-0.016\left[\mathrm{~Pb}^{2+}\right]+0.108[\mathrm{MSA}]
$$

where:

$\sigma$, conductivity, in $\mathrm{mS} / \mathrm{cm}$

$T$, temperature, in $\mathrm{K}$

$\left[\mathrm{Pb}^{2+}\right], \mathrm{Pb}^{2+}$ concentration, in $\mathrm{g} / \mathrm{L}$

[MSA], free-MSA concentration, in $\mathrm{g} / \mathrm{L}$

The calculated and tested values are compared in Fig. 1 and show very good agreement (Adj. $\mathrm{R}$-Square $=0.987$ ). The relative mean square of errors was calculated as 0.202 by Eq. (9) using 116 tested data points $(N)$.

$$
E . R .=\left[\frac{1}{N} \sum_{i}^{N} \frac{\left(\sigma_{\text {cal. }}-\sigma_{\text {tested }}\right)^{2}}{\sigma_{\text {cal. }}^{2}}\right]^{1 / 2}
$$




\subsection{Electrorefining process}

\subsubsection{Effect of current density}

The effect of current density from $105 \mathrm{~A} / \mathrm{m}^{2}$ to $300 \mathrm{~A} / \mathrm{m}^{2}$ on cell voltage, specific energy consumption and surface appearance of cathodic lead was studied using a lead concentration of $120.63 \mathrm{~g} / \mathrm{L}$, a free-MSA concentration of $101.27 \mathrm{~g} / \mathrm{L}$, an electrode spacing of $4.5 \mathrm{~cm}$, a temperature of $293.5 \mathrm{~K}$, an animal glue dosage of $0.08 \mathrm{~g} / \mathrm{L}$, a lignosulfonic acid calcium salt concentration of $0.06 \mathrm{~g} / \mathrm{L}$, and a $\beta$-naphthol concentration of $0.03 \mathrm{~g} / \mathrm{L}$. The selection and dosages of additives were studied in some exploratory experiments. Animal glue and $\beta$-naphthol were necessary for the production of smooth and flat cathodic lead. Lignosulfonic acid calcium salt was helpful for the uniform dissolution of the raw lead anode. In general, the cell voltage and specific energy consumption were low and the quality of cathodic lead was excellent under the conditions tested. The variation of cell voltage and specific energy consumption with current density are presented in Fig. 2. Fig. 3 shows the surface appearance of cathodic lead at different current density.

As was expected, cell voltage and specific energy consumption of the electrorefining process increase with an increase of current density. The cathodic lead were obtained with good surface appearance using a current density below $300 \mathrm{~A} / \mathrm{m}^{2}$ while the average cell voltage and specific energy consumption are less than $0.42 \mathrm{~V}$ and $109.42 \mathrm{~kW} . \mathrm{h} / \mathrm{t}-\mathrm{Pb}$ within a 24 hour depositing cycle, respectively. The results show excellent energy efficiency and that good quality of cathodic lead can be obtained at high current density operation. The dendrites on the cathode edges appear when a current density of greater than $300 \mathrm{~A} / \mathrm{m}^{2}$ is used, but a good surface appearance of cathodic lead may be obtained if there is a further optimization of additive parameters. The cathodic current efficiencies for most of these experiments were nearly $100 \%$. Considering the specific energy consumption, cathodic lead surface appearance and productivity, a current density range from 150 $\mathrm{A} / \mathrm{m}^{2}$ to $250 \mathrm{~A} / \mathrm{m}^{2}$ is reasonable for further experimentation.

\subsubsection{Effect of electrode spacing}

The effect of electrode spacing from $3.0 \mathrm{~cm}$ to $6.0 \mathrm{~cm}$ on cell voltage is showed in Fig. 4 using a current density $150 \mathrm{~A} / \mathrm{m}^{2}$ and all other parameters same as section 4.2.1. The figure shows the cell voltage increases linearly from $0.21 \mathrm{~V}$ to $0.30 \mathrm{~V}$ when the electrode spacing increased from $3.0 \mathrm{~cm}$ to $6.0 \mathrm{~cm}$. The selection of electrode spacing depends on the desired specific energy consumption and cathodic lead thickness. The specific energy consumption will increase when the electrode spacing increases greatly. If the electrode spacing is small, a short circuit between anode and cathode may occur. The effect of electrode spacing on the surface appearance of cathodic lead is insignificant in this work. In this work, an electrode spacing of $4.5 \mathrm{~cm}$ (midway in the range) was chosen for further study. 


\subsubsection{Effect of electrorefining temperature}

The effect of electrorefining temperature from 293.5 to $318 \mathrm{~K}$ on cell voltage and specific energy consumption is shown in Fig. 5 using a current density of $150 \mathrm{~A} / \mathrm{m}^{2}$ and all other parameters the same as section 4.2.1. The figure shows the cell voltage and specific energy consumption decreases with an increase of electrorefining temperature, mainly as a result of the conductivities of lead - MSA solutions increasing with an increase of temperature. The average cell voltage and specific energy consumption decreases from $0.25 \mathrm{~V}$ and $63.90 \mathrm{~kW} \cdot \mathrm{h} / \mathrm{t}-\mathrm{Pb}$ to 0.22 $\mathrm{V}$ and $56.80 \mathrm{~kW} \cdot \mathrm{h} / \mathrm{t}-\mathrm{Pb}$ as the electrorefining temperature was increased from 293.5 to $318 \mathrm{~K}$, respectively. In practice, the comprehensive energy consumption of the electrorefining process must be considered. Although increasing the electrorefining temperature can reduce the specific energy consumption, energy may be required to heat the MSA solution.

The effect of electrorefining temperature at $303 \mathrm{~K}, 308 \mathrm{~K}$ and $318 \mathrm{~K}$ on the surface appearance of the cathodic lead is presented in Fig.6. The color of the lead deposit in Fig.6 (b) is different from others, which is because of the oxidation of lead surface. Furthermore, there are some vertical striations, sharp edges and corners on the surface of Fig.6 (c). The main reason is the cathode reaction rate becomes faster and the electrochemical performance of the additives becomes limiting. The grains of lead are deposited at a coarser size. Considering the specific energy consumption and surface appearance of cathodic lead, the electrorefining temperature which is in the range from 293.5 to $313 \mathrm{~K}$ is desirable for further testing.

\subsubsection{Effect of lead concentration}

Fig.7 shows the effect of lead concentration from 59.24 to $151.18 \mathrm{~g} / \mathrm{L}$ on the cell voltage and specific energy consumption using a current density of $105 \mathrm{~A} / \mathrm{m}^{2}$ and all other parameters the same as section 4.2.1. As mentioned in 4.2.1, it has a lower energy consumption and better surface appearance of cathodic lead under the current density of $105 \mathrm{~A} / \mathrm{m}^{2}$. And considering the future developments trends of electrorefining for production of pure lead which is low current density and long term electrorefining, we selected the current density as $105 \mathrm{~A} / \mathrm{m}^{2}$ to test the range of lead concentration, especially to test the critical value of lead concentration which may cause the surface appearance of cathodic lead to degrade. The results show that the average cell voltage and specific energy consumption of the electrorefining process from MSA medium decreases from $0.20 \mathrm{~V}$ and $51.00 \mathrm{~kW} . \mathrm{h} / \mathrm{t}-\mathrm{Pb}$ to $0.15 \mathrm{~V}$ and $39.70 \mathrm{~kW} . \mathrm{h} / \mathrm{t}-\mathrm{Pb}$ respectively as the lead concentration was increased from 59.24 to $151.18 \mathrm{~g} / \mathrm{L}$. In the work the results are not predicted from the theory (and measurement) of conductivities of lead - MSA solutions. The reason may be that the solubility of lead in MSA is $2.6 \mathrm{M} / \mathrm{dm}^{3}$ at $295 \mathrm{~K}$ [11] which is very high, but in the work the lead concentrations are relatively low. Probably in this range of lead concentration, the effect of lead concentration on the conductivities is less than the effect of free-MSA concentration on the conductivities. The specific resistance of the electrolyte relies on the free-MSA concentration.

Fig. 8 shows the effect of lead concentration on the surface appearance of the cathodic lead. It shows the surface appearance is acceptable as the lead concentration was decreased from 151.18 to $59.24 \mathrm{~g} / \mathrm{L}$, but it can be predicted from Fig.8 (d), which had began to grow small particles and develop vertical features, the surface appearance of cathodic lead may become worse as lead 
concentration less than $60 \mathrm{~g} / \mathrm{L}$. Hence, in this work, the electrorefining process under the lead concentration in the range from 60 to $150 \mathrm{~g} / \mathrm{L}$ is feasible, but practically the energy consumption must also be considered.

\subsubsection{Effect of free-MSA concentration}

The effect of the free-MSA concentration from 49.72 to $149.73 \mathrm{~g} / \mathrm{L}$ on cell voltage and specific energy consumption is showed on Fig. 9 using a current density $150 \mathrm{~A} / \mathrm{m}^{2}$ and all other parameters the same as section 4.2.1. The results show that the average cell voltage and specific energy consumption decrease from $0.37 \mathrm{~V}$ and $96.80 \mathrm{~kW} \cdot \mathrm{h} / \mathrm{t}-\mathrm{Pb}$ to $0.21 \mathrm{~V}$ and $55.20 \mathrm{~kW} \cdot \mathrm{h} / \mathrm{t}-\mathrm{Pb}$ with an increase of free-MSA concentration from 49.72 to $149.73 \mathrm{~g} / \mathrm{L}$, respectively.

Fig.10 shows the effect of the free-MSA concentration on surface appearance of the cathodic lead. The results show that the dendrites can be produced at the edges of the cathode when the free-MSA concentration is less than $80 \mathrm{~g} / \mathrm{L}$. The reason is that the cathode reaction is effected by electrolyte resistance, which is high at low free-MSA concentration. At the same time, the lead concentration is high and the free-MSA concentration is low at the surface of cathode edges, but the electric flux line is strong at the cathode edges, so that the grains at the cathode edges grow faster and form dendrites quickly. Considering the specific energy consumption, surface appearance of cathodic lead and MSA consumption, the optimum free-MSA concentration appears to be $100 \mathrm{~g} / \mathrm{L}$ and all further experiments were carried out at this free-MSA concentration.

\subsubsection{Effect of electrorefining time}

A electrorefining experiment was performed for 3 days using a current density $150 \mathrm{~A} / \mathrm{m}^{2}$, lead concentration $118.81 \mathrm{~g} / \mathrm{L}$, free-MSA $99.64 \mathrm{~g} / \mathrm{L}$, electrode spacing $4.5 \mathrm{~cm}$, temperature 293.5 $\mathrm{K}$, an animal glue dosage of $0.08 \mathrm{~g} / \mathrm{L}$, a lignosulfonic acid calcium salt concentration of $0.06 \mathrm{~g} / \mathrm{L}$, and a $\beta$-naphthol concentration of $0.03 \mathrm{~g} / \mathrm{L}$. Fig. 11 shows the change of cell voltage with electrorefining time. Overall, the cell voltage increases with an increase of electrorefining time. This is due to the increasing resistance of current flow through the slimes which contributes to a higher anodic polarization and the cathode polarization decreases with longer time [14]. During the electrorefining process, the cell voltage decreases a little at $1820 \mathrm{~min}, 1940 \mathrm{~min}, 2410 \mathrm{~min}$, $2880 \mathrm{~min}$ and $3300 \mathrm{~min}$, then it increases again, maybe as a result of the falling off of some slime from the anode and dissolution of some impurities from anode. In the whole process, the average cell voltage is $0.40 \mathrm{~V}$ and the specific energy consumption is $105.04 \mathrm{~kW} \cdot \mathrm{h} / \mathrm{t}-\mathrm{Pb}$. Compared with the current global practice [1], the specific energy consumption was $143 \mathrm{~kW} \cdot \mathrm{h} / \mathrm{t}-\mathrm{Pb}$. Therefore the electrorefining process for production of pure lead from MSA medium may provide an energy saving relative to conventional practice.

Fig. 12 shows the surface appearance of cathodic lead after 3 days of electrorefining. Fig.13 shows the morphology of the cathodic lead by SEM. The results show that the crystal growth on the cathode was uniform and compact.

Table 6 shows the chemical composition of the cathodic lead by optical emission spectrometric analysis method, AAS and titrimetric method. It shows that the lead content is more than $99.99 \%$. 


\section{Conclusions}

The conductivities of lead - MSA solutions increase with an increase of free-MSA concentration and temperature, respectively. They also increase with an increase of lead concentration without free-MSA. The conductivity decreases with an increase of lead concentration for MSA concentrations of $50-200 \mathrm{~g} / \mathrm{L}$. A mathematical model for all the conductivities was developed as: $\sigma=-44.031+0.172 T-0.016\left[\mathrm{~Pb}^{2+}\right]+0.108[\mathrm{MSA}]$

The electrorefining process for production of pure lead from MSA medium offers low environmental pollution, low energy consumption and high productivity. In this work, the cell voltage and specific energy consumption increase with an increase of current density, electrode spacing and electrorefining time and decreases with an increase of electrorefining temperature, lead concentration and free-MSA concentration.

Some operating parameters of the electrorefining process were established as follows: current density 150 to $250 \mathrm{~A} / \mathrm{m}^{2}$, electrode spacing 3.0 to $6.0 \mathrm{~cm}$, electrorefining temperature 293.5 to 313 $\mathrm{K}$, lead concentration 60 to $150 \mathrm{~g} / \mathrm{L}$, free-MSA concentration $100 \mathrm{~g} / \mathrm{L}$. The cathodic current efficiency for most experiments is excess of 99\%, and the specific energy consumption was below $110 \mathrm{~kW} \cdot \mathrm{h} / \mathrm{t}-\mathrm{Pb}$. The lead content of the cathodic lead was in excess of $99.99 \%$.

\section{Acknowledgements}

The authors gratefully acknowledge Teck Ltd. for providing the anode samples. Dr. Jianming $\mathrm{Lu}$ of UBC is acknowledged for providing assistance with the experimental planning and setup. BASF is thanked for providing samples of MSA and funding for this work. The authors also gratefully acknowledge the Chinese National Science Foundation (51364019) and China Scholarship Council Foundation (201208535053) for the financial support for Dr. Bingjie Jin.

\section{References}

[1] J. A. González-Domínguez, E. Peters, D. B. Dreisinger, The refining of lead by the Betts process, J. Appl. Electrochem. 21(1991)189-202.

[2] M. Tosuke, S. Kazuo, Electrolytic Refining of Lead by Sulfamate Bath, Bulletin of the Research Institute of Mineral Dressing and Metallurgy, Tohoku University. 11(1955)99-108.

[3] M. Schlesinger, M. Paunovic, Modern electroplating, fifth ed. John Wiley and Sons, Inc., Hoboken, New Jersey. 2010.

[4] E. Expósito, J. González-García, P. Bonete, V. Montiel, A. Aldaz, Lead electrowinning in a fluoborate medium. Use of hydrogen diffusion anodes, J. Power Sources. 87(2000)137-143.

[5] P. ZHANG, T. J. O'Keefe, P. YU, Electrochemical characterization of the effects of 
impurities and organic additives in lead electrowinning from fluoborate electrolyte, Hydrometallurgy. 61(2001)207-221.

[6] E. Expósito, J. Iniesta, J. González-García, V. Montiel, A. Aldaz, Lead electrowinning in an acid chloride medium, J. Power Sources. 92(2001)260-266.

[7] Sheia M. Wong, Liusa M. Abrantes, Lead electrodeposition from very alkaline media,. Electrochim. Acta. 51(2005)619-626.

[8] D. CH. ZHANG, T. Z. YANG, W. LIU, W. F. LIU, ZH. F. XIE, Electrorefining of a gold-bearing antimony alloy in alkaline xylitol solution, Hydrometallurgy. 99(2009)151-156.

[9] C. X. Guo, Y. C. ZHAO, Lead electrowinning in a sodium hydroxide medium, Proceeding of the $1^{\text {st }}$ international conference on pollution control and resource reuse for a better tomorrow and sustainable ecomomy, Shanghai, China. 10(2005)754-756.

[10] Y. Y. GU, Q. H. ZHOU, T. Z. YANG, W. LIU, D. CH. ZHANG, Lead electrodeposition from alkaline solutions containing xylitol, Trans. Nonferrous Met. Soc. China. 21(2011)1407-1413.

[11] M. D. Gernon, M. WU, T. Buszta, Environmental benefits of methanesulfonic acid: Comparative properties and advantages, Green Chem. 1(1999)127-140.

[12] Vyacheslav S. Protsenko, Elena A. Vasil'eva, Felix I. Danilov, ELECTRODEPOSITION OF LEAD COATINGS FROM A METHANESULPHONATE ELECTROLYTE, J. Chem. Technol. Met. 50(2015)39-43.

[13] M. D. CAPElato, J. A. NOBREGA. E. F. A. NEVES, Complexing power of alkanesulfonate ions: the lead-methanesulfonate system, J. Appl. Electrochem. 25(1995)408-411.

[14] T. Dobrev, S. Rashkov, Processes during the electrorefining and electrowinning of lead, Hydrometallurgy. 40(1996)277-291. 
Table 1

Chemical composition of the raw lead

\begin{tabular}{|c|c|c|c|c|c|c|c|c|c|}
\hline \multicolumn{10}{|c|}{ Constituent (\%) } \\
\hline $\mathrm{Pb}$ & As & $\mathrm{Sb}$ & $\mathrm{Bi}$ & $\mathrm{Fe}$ & $\mathrm{Sn}$ & $\mathrm{Zn}$ & $\mathrm{Cu}$ & $\mathrm{Ag}$ & $\mathrm{Au}$ \\
\hline 96.540 & 0.577 & 1.150 & 0.852 & 0.025 & 0.053 & 0.006 & 0.003 & 0.669 & 0.002 \\
\hline
\end{tabular}

Table 2

Conductivities of lead - MSA solutions at $293.5 \mathrm{~K}(\mathrm{mS} / \mathrm{cm})$

\begin{tabular}{cccccc}
\hline \multirow{2}{*}{$\mathrm{Pb}^{2+}$ concentration $(\mathrm{g} / \mathrm{L})$} & \multicolumn{5}{c}{ Free MSA concentration $(\mathrm{g} / \mathrm{L})$} \\
\cline { 2 - 6 } & 0 & 50 & 100 & 150 & 200 \\
\hline 0 & & 13.59 & 19.93 & 23.50 & 27.10 \\
30 & 2.04 & 13.22 & 19.57 & 22.90 & 25.30 \\
50 & 2.90 & 13.02 & 18.78 & 22.40 & 24.50 \\
100 & 4.50 & 12.61 & 18.40 & 21.10 & 23.20 \\
150 & 5.52 & 12.03 & 17.63 & 20.40 & 21.60 \\
200 & 6.09 & 11.14 & 15.89 & 19.23 & 20.30 \\
\hline
\end{tabular}

Table 3

Conductivities of lead - MSA solutions at $303 \mathrm{~K}(\mathrm{mS} / \mathrm{cm})$

\begin{tabular}{cccccc}
\hline \multirow{2}{*}{$\mathrm{Pb}^{2+}$ concentration $(\mathrm{g} / \mathrm{L})$} & \multicolumn{5}{c}{ Free MSA concentration $(\mathrm{g} / \mathrm{L})$} \\
\cline { 2 - 6 } & 0 & 50 & 100 & 150 & 200 \\
\hline 0 & & 14.28 & 21.2 & 25.90 & 28.80 \\
30 & 2.48 & 13.86 & 20.5 & 25.20 & 27.30 \\
50 & 3.49 & 13.50 & 20.2 & 24.00 & 26.70 \\
100 & 5.28 & 13.16 & 19.78 & 22.80 & 25.70 \\
150 & 6.49 & 12.71 & 19.64 & 21.80 & 23.50 \\
200 & 7.27 & 11.87 & 17.64 & 20.40 & 21.90 \\
\hline
\end{tabular}

Table 4

Conductivities of lead - MSA solutions at $313 \mathrm{~K}(\mathrm{mS} / \mathrm{cm})$

\begin{tabular}{cccccc}
\hline \multirow{2}{*}{$\mathrm{Pb}^{2+}$ concentration $(\mathrm{g} / \mathrm{L})$} & \multicolumn{5}{c}{ Free MSA concentration $(\mathrm{g} / \mathrm{L})$} \\
\cline { 2 - 6 } & 0 & 50 & 100 & 150 & 200 \\
\hline 0 & & 15.46 & 23.00 & 28.20 & 30.80 \\
30 & 2.94 & 15.03 & 22.50 & 27.10 & 29.10 \\
50 & 4.12 & 14.63 & 22.10 & 26.30 & 28.50 \\
100 & 6.24 & 14.18 & 21.30 & 25.10 & 28.10 \\
150 & 7.63 & 13.76 & 21.00 & 23.30 & 26.80 \\
200 & 8.50 & 13.42 & 19.46 & 22.50 & 24.70 \\
\hline
\end{tabular}


Table 5

Conductivities of lead - MSA solutions at $323 \mathrm{~K}(\mathrm{mS} / \mathrm{cm})$

\begin{tabular}{cccccc}
\hline \multirow{2}{*}{$\mathrm{Pb}^{2+}$ concentration $(\mathrm{g} / \mathrm{L})$} & \multicolumn{5}{c}{ Free MSA concentration $(\mathrm{g} / \mathrm{L})$} \\
\cline { 2 - 6 } & 0 & 50 & 100 & 150 & 200 \\
\hline 0 & & 16.78 & 25.20 & 31.70 & 35.00 \\
30 & 3.22 & 16.33 & 24.50 & 29.90 & 33.10 \\
50 & 4.59 & 15.81 & 24.10 & 29.00 & 32.60 \\
100 & 6.86 & 15.10 & 23.50 & 27.90 & 31.50 \\
150 & 8.41 & 14.81 & 23.20 & 26.70 & 29.60 \\
200 & 9.37 & 14.17 & 21.10 & 25.40 & 27.80 \\
\hline
\end{tabular}

Table 6

Chemical composition of the cathodic lead

Constituent

(\%)

\begin{tabular}{lllllllll}
\hline $\mathrm{Pb}$ & $\mathrm{Ag}$ & $\mathrm{Cu}$ & $\mathrm{Bi}$ & $\mathrm{As}$ & $\mathrm{Sb}$ & $\mathrm{Sn}$ & $\mathrm{Zn}$ & $\mathrm{Fe}$ \\
$>99.99$ & $<0.0005$ & $<0.0005$ & $<0.0003$ & $<0.0003$ & $<0.0008$ & $<0.0005$ & $<0.0003$ & $<0.0005$ \\
\hline
\end{tabular}


Figure captions:

Fig. 1 Comparison of calculated and tested values of conductivities

Fig.2 Effect of current density on cell voltage and specific energy consumption

Fig.3 Effect of current density on surface appearance of cathodic lead (a) $105 \mathrm{~A} / \mathrm{m}^{2}$, (b) $150 \mathrm{~A} / \mathrm{m}^{2}$, (c) $200 \mathrm{~A} / \mathrm{m}^{2}$, (d) $250 \mathrm{~A} / \mathrm{m}^{2}$, (e) $300 \mathrm{~A} / \mathrm{m}^{2}$

Fig.4 Effect of electrode spacing on cell voltage

Fig.5 Effect of electrorefining temperature on cell voltage and specific energy consumption

Fig.6 Effect of electrorefining temperature on surface appearance of cathodic lead (a) $303 \mathrm{~K}$, (b) $308 \mathrm{~K}$, (c) $318 \mathrm{~K}$

Fig.7 Effect of lead concentration on cell voltage and specific energy consumption

Fig.8 Effect of lead concentration on the surface appearance of cathodic lead (a) $151.18 \mathrm{~g} / \mathrm{L}$, (b) $99.62 \mathrm{~g} / \mathrm{L}$, (c) $81.13 \mathrm{~g} / \mathrm{L}$, (d) $59.24 \mathrm{~g} / \mathrm{L}$

Fig.9 Effect of free-MSA concentration on cell voltage and energy consumption

Fig.10 Effect of free-MSA concentration on surface appearance of cathodic lead (a) $\quad 49.72 \mathrm{~g} / \mathrm{L}$, (b) $80.61 \mathrm{~g} / \mathrm{L}$, (c) $118.47 \mathrm{~g} / \mathrm{L}$, (d) $149.73 \mathrm{~g} / \mathrm{L}$

Fig. 11 Change of cell voltage with electrorefining time

Fig. 12 Surface appearance of cathodic lead under 3 days electrorefining

Fig.13 Morphology of cathodic lead under 3 day's electrorefining (a) 10000X, (b) $8000 \mathrm{X}$ 


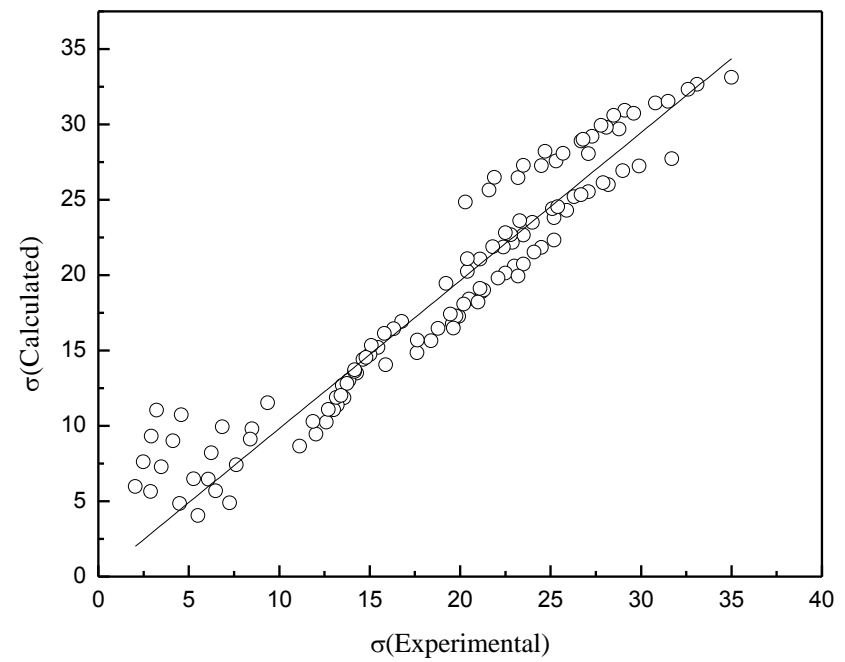

Fig. 1

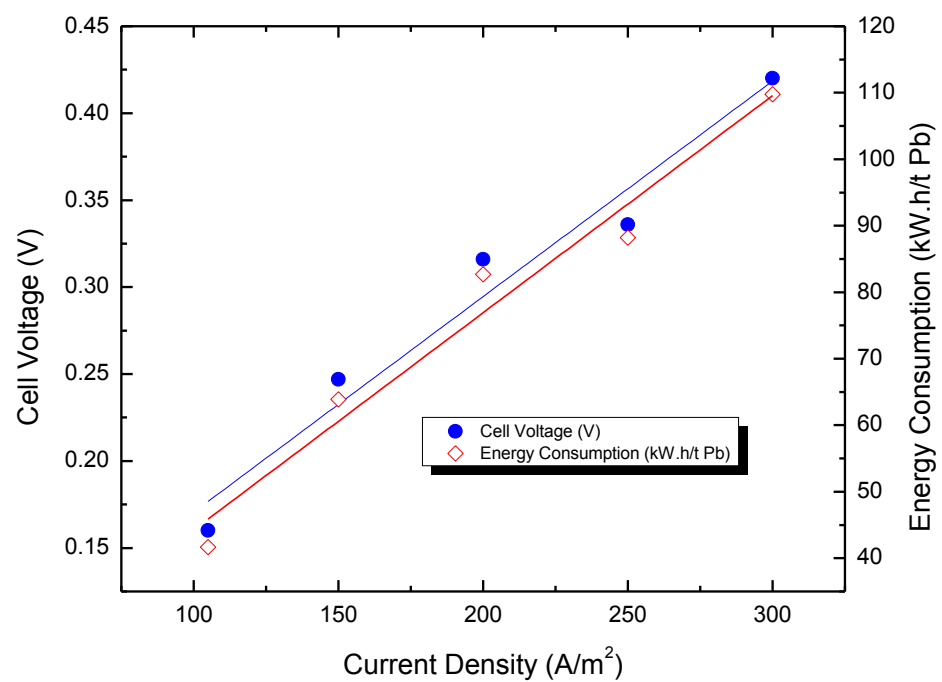

Fig.2

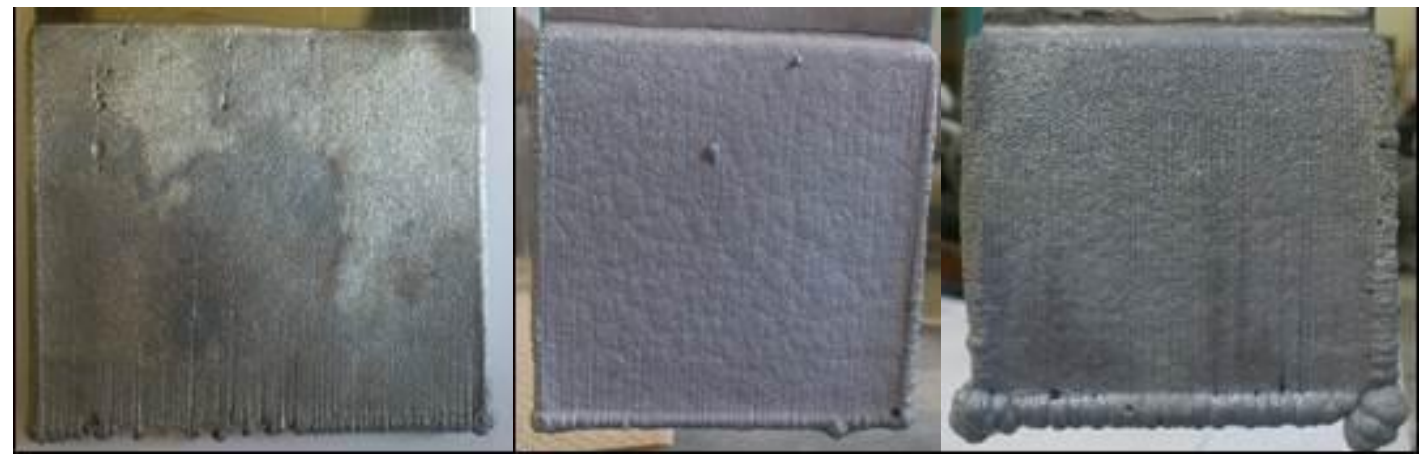

(a)

(b)

(c) 


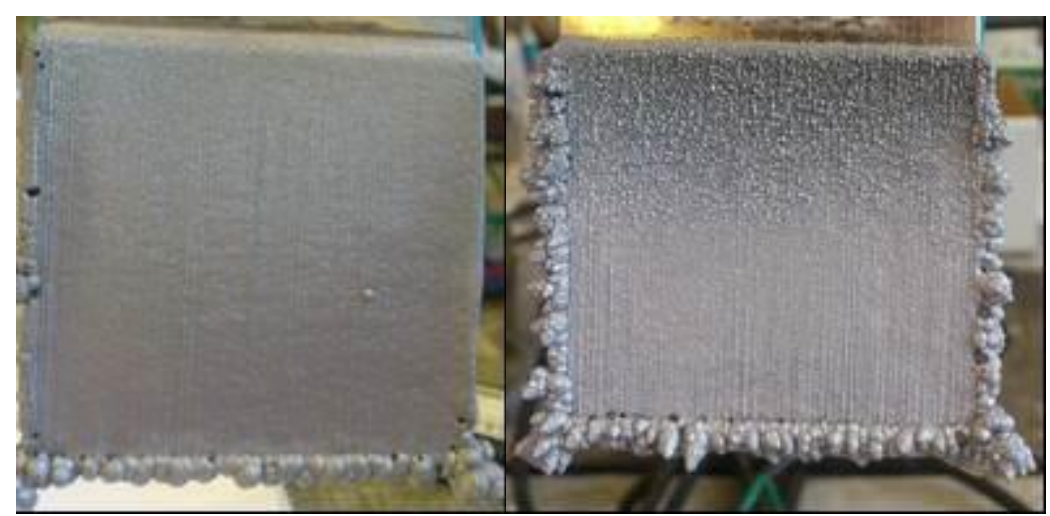

(d)

(e)

Fig. 3

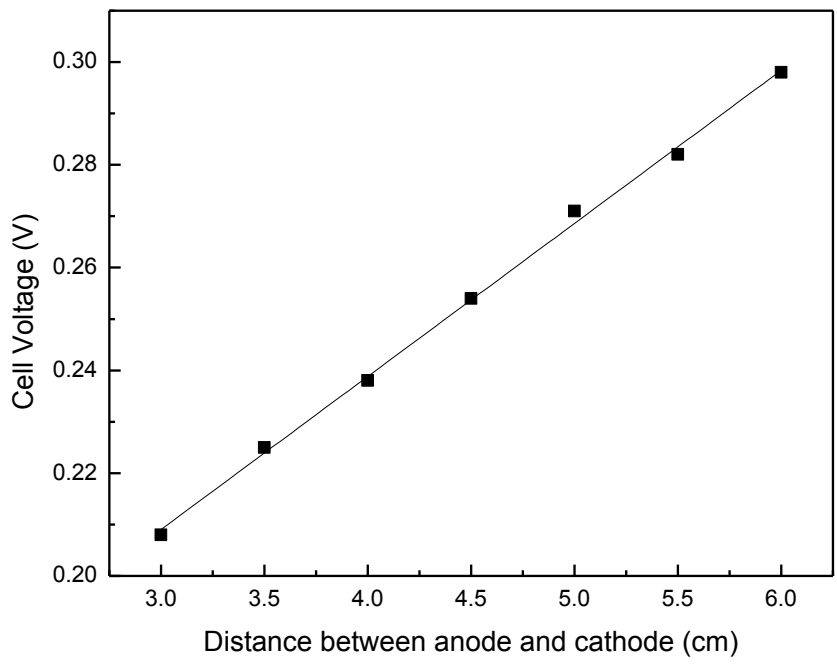

Fig.4 


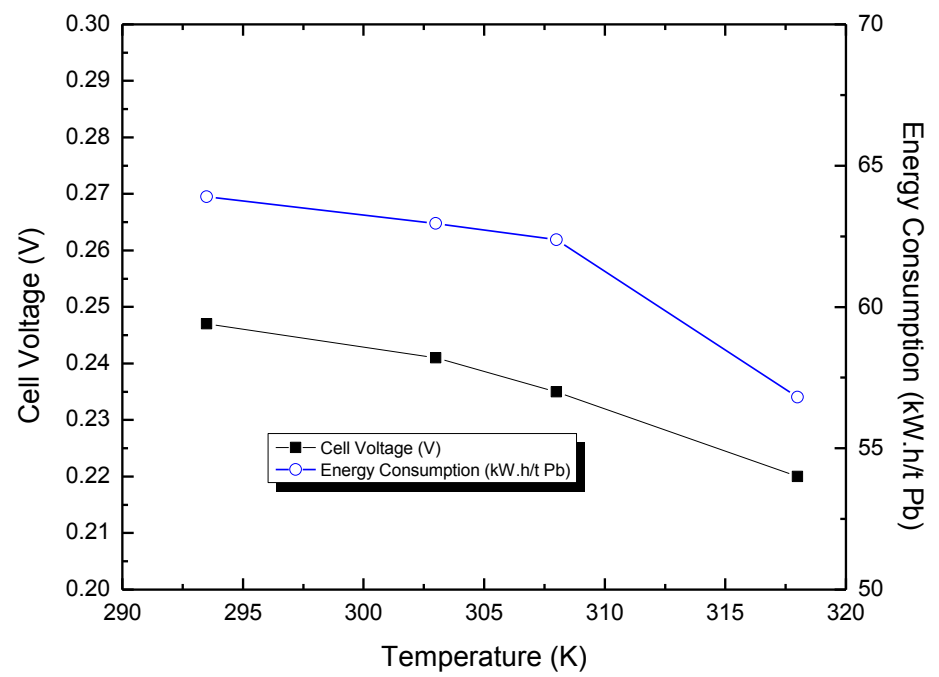

Fig.5

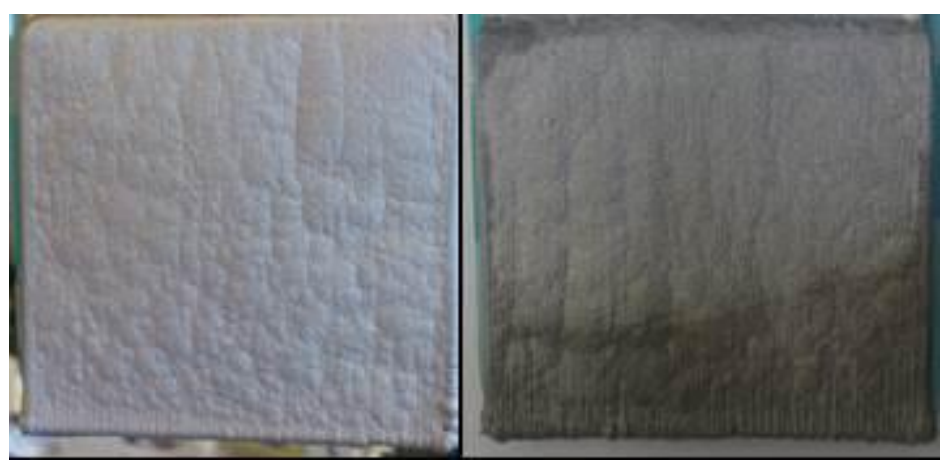

(a)

(b)

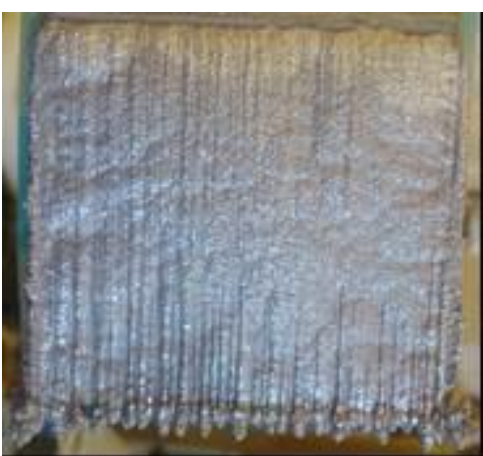

(c)

Fig.6

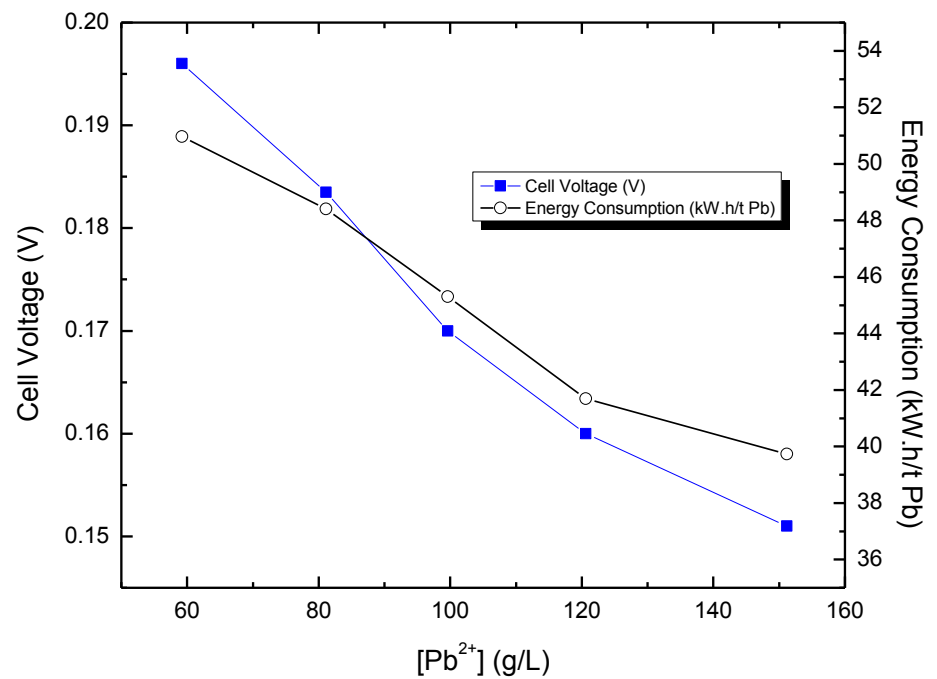


Fig.7

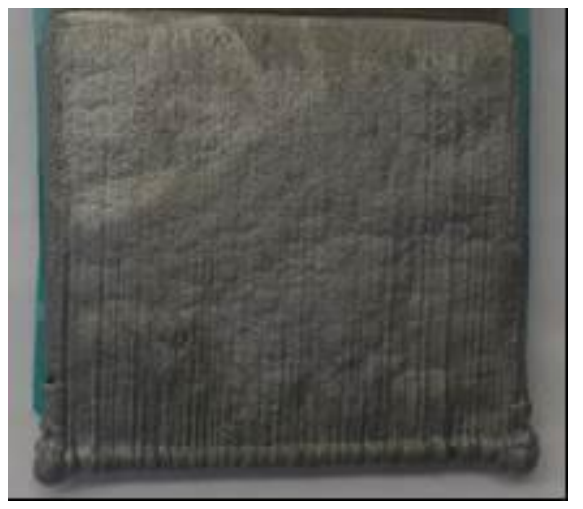

(a)

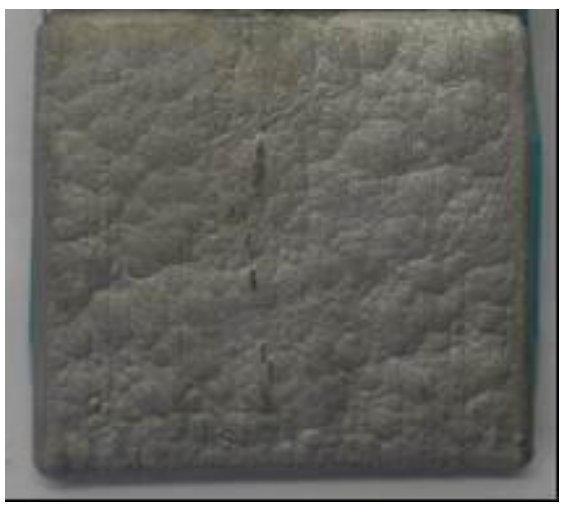

(c)

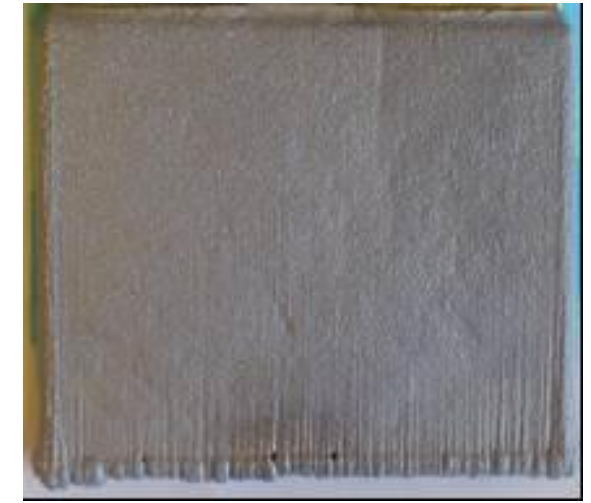

(b)

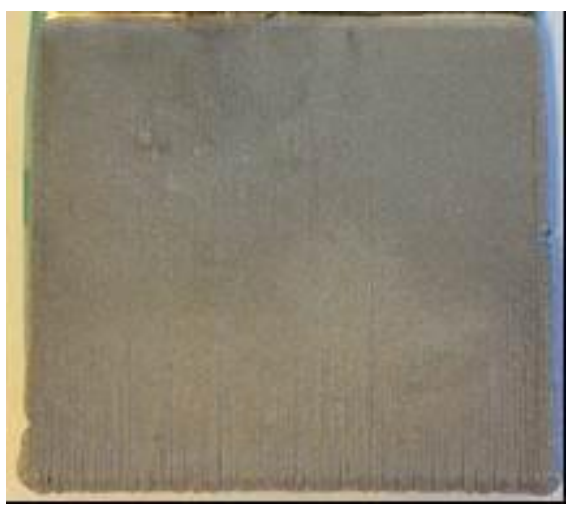

(d)

Fig.8

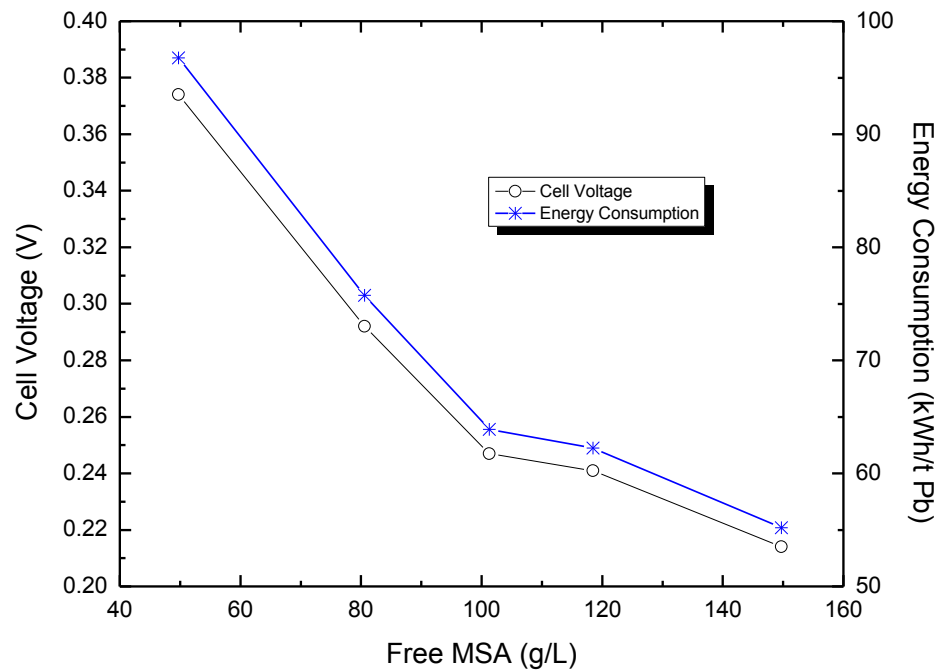

Fig.9 


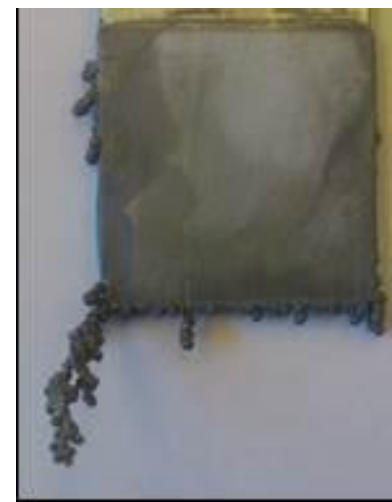

(a)

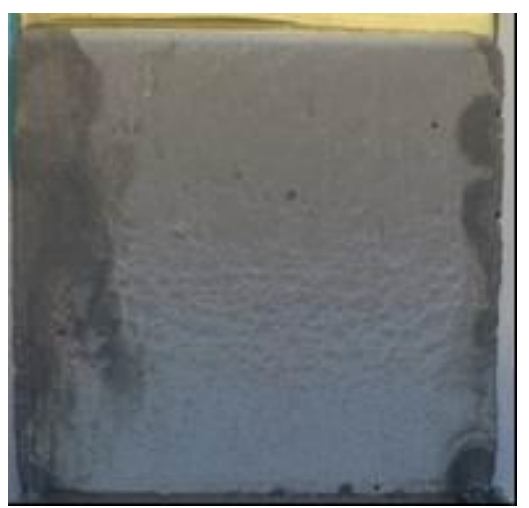

(c)

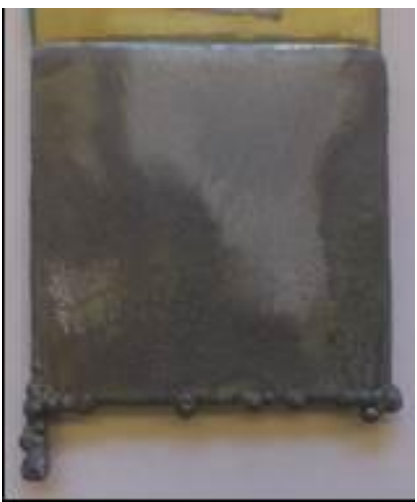

(b)

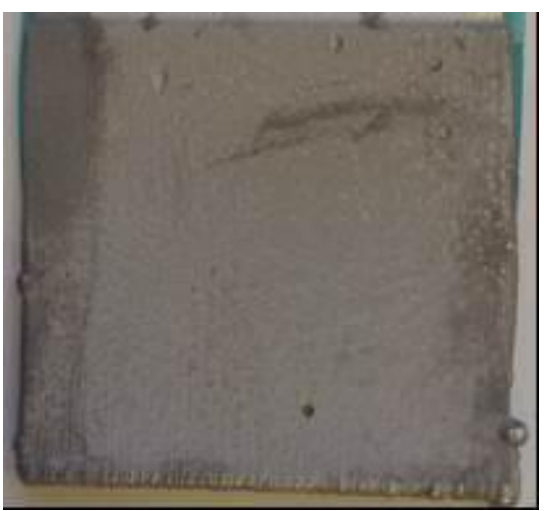

(d)

Fig.10

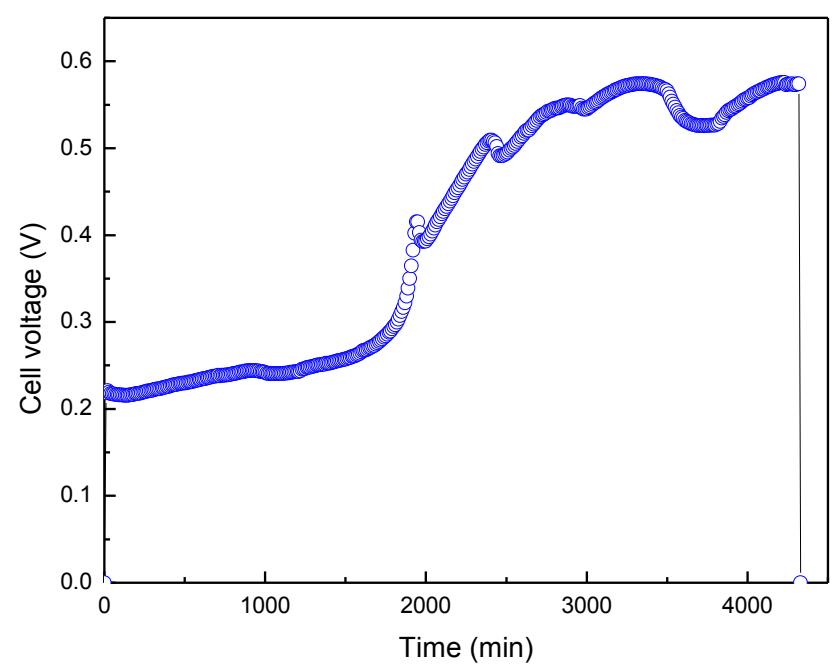

Fig. 11 


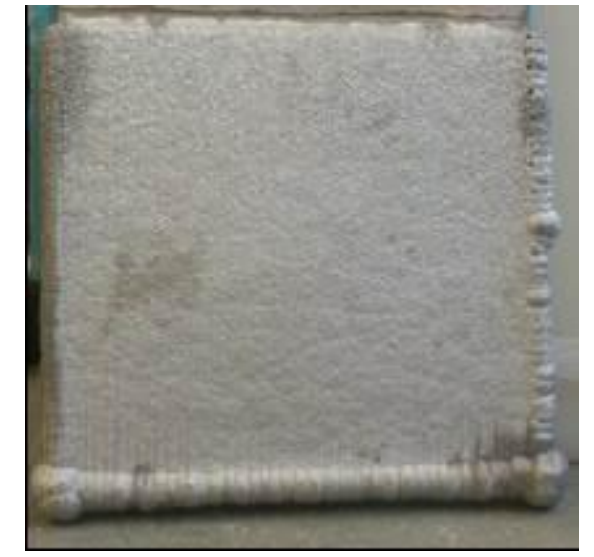

Fig. 12

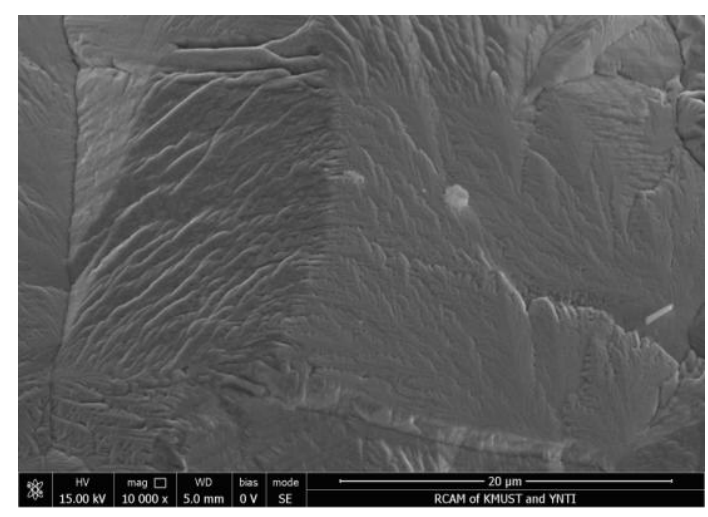

(a)

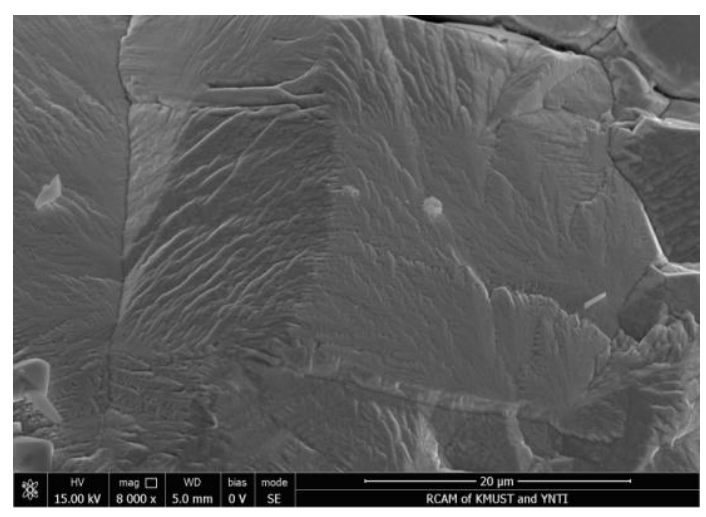

(b)

Fig.13 